\title{
PENINGKATAN KEPUASAN DAN KINERJA KARYAWAN MELALUI MANAJEMEN PERENCANAAN KARIR
}

\section{EMPLOYEE SATISFACTION AND PERFORMANCE IMPROVEMENT BY CAREER PLANNING MANAGEMENT}

\author{
Zulfadli Hamzah \\ Universitas Islam Riau \\ zulfadlihamzah@fis.uir.ac.id
}

\begin{abstract}
The success of an organization is inseparable from the increase in human resources. This study aims to analyze the career planning process Baitul Maal waa Tamwil (BMT) and its impact on employee performance and job satisfaction. The study was conducted using a quantitative approach. The study population was all employees while the number of samples in this study were 79 people using total sampling techniques. Hypothesis test used in this study was SEM (Structural Equation Modeling) with the PLS program. The results of this study indicate that there is a direct influence between careers planning on employee performance, there is a direct influence between career planning on employee Job Satisfaction, there is a direct effect between satisfaction on employee performance, there is an indirect effect between career planning on performance through employee job satisfaction. Based on the results of the study, make a clear career plan for their employees so that they are more enthusiastic in working and will create job satisfaction which will ultimately improve their performance.
\end{abstract}

Keywords: Career Planning, Job Satisfaction and Employee Performance.

\begin{abstract}
ABSTRAK
Keberhasilan suatu organisasi tidak terlepas dari peningkatan sumber daya manusia. Penelitian ini bertujuan untuk menganalisa proses perencanaan karir Baitul Maal waa Tamwil (BMT) serta dampaknya terhadap kinerja dan kepuasan kerja karyawan. Penelitian dilakukan menggunakan pendekatan kuantitatif. Populasi penelitian ini adalah seluruh karyawan, sedangkan jumlah sampel dalam penelitian ini sebanyak 79 orang dengan menggunakan teknik total sampling. Pengujian hipotesis dalam penelitian ini mengunakan SEM (Structural Equation Modeling) dengan program PLS. Hasil penelitian ini menunjukkan bahwa terdapat pengaruh langsung antara perencanaan karir terhadap kinerja karyawan, terdapat pengaruh langsung antara perencanaan karir terhadap Kepuasan Kerja karyawan, terdapat pengaruh langsung antara kepuasan terhadap kinerja karyawan, terdapat pengaruh tidak langsung antara perencanaan karir terhadap kinerja melalui kepuasan kerja karyawan. Berdasarkan hasil penelitian harapkan kepada seluruh BMT untuk membuat perencanaan karir yang jelas bagi karyawannya supaya mereka lebih bersemangat dalam bekerja dan akan meninbulkan kepuasan kerja yang akhirnya akan meningkatkan kinerja mereka.
\end{abstract}

Kata Kunci : Perencanaan Karir, Kepuasan Kerja dan Kinerja Karyawan. 


\section{PENDAHULUAN}

Sebagian besar lembaga keuangan yang beroperasi di Indonesia merupakan lembaga keuangan yang berbasis konvensional yang mempraktekkan konsep bunga (riba) di setiap produk yang mereka tawarkan. Namun sejak tahun 1992, telah muncul lembaga keuangan yang berbasis syariah yang melarang praktek konsep bunga (riba) pada operasional mereka.Lembaga keuangan syariah itu ialah Bank Muamalat Indonesia (BMI) yang didirikan atas inisiafif dari MUI. Pendirian lembaga keuangan syariah ini menjadi batu loncatan bagi MUI untuk mendirikan lembaga keuangan syariah lainnya seperti Baitul Maal Wat Tamwil (BMT).

BMT ialah lembaga keuangan syariah yang beroperasi menggunakan gabungan konsep "Baitul Maal" dan "Baitul Tamwil" dengan target operasionalnya fokus kepada sektor Usaha Kecil Menengah (UKM). Konsep Baitul maal berarti BMT berperan sebagai lembaga sosial keagamaan yang mempunyai fungsi untuk menerima dana Zakat, Sedekah, Infaq dan Waqaf dan menyalurkan kepada yang berhak menerima dana tersebut. Sedangkan pada konsep Baitul Tamwil, BMT mempunyai peranan sebagai lembaga bisnis maupun lembaga keuangan yang bertujuan untuk mencari keuntungan (profit oriented) seperti membuka Toserba (toko serba ada) atau menawarkan produk simpan pinjam ke masyarakat. Namun jika kita lihat prakteknya dilapangan, BMT lebih cenderung berperan sebagai lembaga keuangan shariah yang menawarkan produk simpan pinjam ke masyarakat yang berlandaskan pada prinsip syariah.

Pada hakikatnya konsep BMT tersebut sudah ada di Indonesia sejak tahun 1992 yang dipelopori oleh Aries Mufti dengan mendirikan BMT Bina Insan Kamil di Jakarta Pusat. Walau bagaimanapun, BMT secara resmi didirikan pada tahun 1995 setelah Bank Muamalat Indonesia (BMI) sebagai Bank Islam pertama di Indonesia dibentuk. Pendirian BMT ketika itu didirikan berdasarkan inisiatif dari ICMI (Ikatan Cendikiawan Muslim Indonesia), MUI (Majlis Ulama Indonesia) dan BMI (Bank Muamalat Indonesia). Dan BMT mulai beroperasi di bawah pengawasan PINBUK (Pusat Inkubasi Usaha Kecil) pada tahun yang sama.

Kota Pekanbaru adalah ibukota provinsi Riau yang mayoritas penduduknya beragama Islam dan berbudaya melayu dengan luas wilayah 8.915.016 KM2 dan jumlah penduduk 1,2 juta jiwa (2018) yang sebagian besar penduduknya bekerja di sektor jasa dan perdagangan. Dalam beberapa tahun terakhir kota pekanbaru mengalami perkembangan yang pesat baik itu dari sektor pembangunan maupun sektor perekonomian. Sehingga ini menjadi potensi yang besar untuk perkembangan Baitul Maal Wat Tamwil (BMT) yang ada di Kota pekanbaru. Adapun jumlah BMT yang ada di Kota Pekanbaru adalah sebagai berikut : 
Tabel 1. Daftar List Baitul Maal Wat Tamwil (BMT) di Kota Pekanbaru

\begin{tabular}{|c|c|c|}
\hline No & Nama BMT & Alamat \\
\hline 1. & BMT Al Amin & Jl. Pasir putih No 3 \\
\hline 2. & BMT Mutiara Sakinah & J1. Purnama Ujung No. 2 \\
\hline 3. & $\begin{array}{l}\text { BMT UGT Sidogiri } \quad \text { Cabang } \\
\text { Pekanbaru }\end{array}$ & $\begin{array}{l}\text { J1. Delima No.17, Delima, } \\
\text { Tampan }\end{array}$ \\
\hline 4. & BMT Al Ittihad & $\begin{array}{l}\text { Komplek Damar\#610 Camp } \\
\text { Chevron Rumbai . }\end{array}$ \\
\hline 5. & BMT Islam Abdurrab & Jl. Riau Ujung No. 73 \\
\hline 6. & BMT Al Hijrah & J1. Tuanku Tambusai \\
\hline 7. & BMT Mitra Arta & $\begin{array}{l}\text { J1. Sekolah / Khayangan } \\
\text { No.80 E, Limbungan Baru, } \\
\text { Rumbai Pesisir. }\end{array}$ \\
\hline 8. & BMT Septa Bina Usaha & $\begin{array}{l}\text { J1. Kaharudin Nasution, No. } \\
\text { 01, Bukit Raya, Maharatu, } \\
\text { Marpoyan Damai }\end{array}$ \\
\hline 9. & BMT Permata Indonesia & Jl. Rawa Mangun, Parit Indah. \\
\hline 10. & BMT Darussalam & $\begin{array}{l}\text { Jl. Kaharuddin Nasution No } \\
\text { 113, Perhentian Marpoyan }\end{array}$ \\
\hline 11. & BMT Marwah & $\begin{array}{lr}\text { Jl. Paus Indah } & \text { I No.34, } \\
\text { Tengkerang } & \text { Tengah, } \\
\text { Marpoyan Damai. } & \\
\end{array}$ \\
\hline
\end{tabular}

Sumber : Data Olahan 2019

Berdasarkan penelitian yang dilakukan oleh Hamzah et al., (2013) menemukan bahwa terdapat permasalahan-permasalahan yang di hadapi oleh BMT yang ada di Kota Pekanbaru, diantaranya yang paling dominan adalah masalah kualitas dan kinerja Karyawan Baitul Maal Wat Tamwil (BMT). Sehingga permasalahan ini menjadi pembahasan yang menarik untuk di bahas dan di teliti. Keberhasilan suatu organisasi tidak terlepas dari peningkatan sumber daya manusia Susilaningsih (2008) mengatakan bahwa. Sumber daya manusia yang unggul dan berkualitas harus selalu dikelola dan ditekankan oleh organisasi untuk dapat mencapai kinerja yang diharapkan. Oleh karena itu, peningkatan kualitas sumber daya manusia sangat diperlukan agar karyawan memiliki sifat dan perilaku yang mampu memberikan pelayanan dan pengayoman serta memberikan kesejahteraan lahir batin bagi masyarakat.
Kinerja merupakan hasil kerja yang dicapai oleh pegawai atau perilaku nyata yang ditampilkan sesuai dengan organisasi. performance atau kinerja merupakan output drive from process, human or otherwise, jadi dikatakan bahwa kinerja merupakan hasil atau keluaran dari suatu proses (Indrawati 2013). Berdasarkan pendapat diatas, maka dapat disimpulkan bahwa kinerja karyawan adalah hasil kerja secara kualitas dan kuantitas yang dicapai oleh seorang pegawai yang merefleksikan seberapa baik karyawan memenuhi persyaratan untuk mencapai tujuan organisasi atau perusahaan.

Kepuasan kerja merupakan evaluasi yang menggambarkan seseorang atas perasaan sikapnya, senang atau tidak senang, puas atau tidak puas dalam bekerja. Setiap individu akan mempunyai tingkat kepuasan yang berbeda-beda tergantung penilaian individu terhadap aspek-aspek pekerjaan 
seperti, bayaran, promosi jabatan, kondisi kerja,rekan kerja, dan pengawasan yang dirasakan sesuai dengan keinginan individu tersebut (Purwati et al., 2018). Semakin banyak aspek-aspek dalam pekerjaan yang sesuai dengan keinginan individu tersebut, maka semakin tinggi tingkat kepuasan yang dirasakannya dan apabila semakin sedikit aspek-aspek dalam pekerjaan tersebut yang sesuai dengan keinginan individu, maka semakin rendah tingkat kepuasan yang dirasakannya. Hasil penelitian yang dilakukan oleh Muhammad (2019) menemukan bahwa Kepuasan Kerja berpengaruh positif dan signifkan terhadap Kinerja karyawan Divisi Mikro Mitra Usaha Rakyat (MUR) PT. Bank BTPN cabang Pekanbaru. Hasil penelitian yang sama juga dilakukan oleh Rusby \& Hamzah (2017) yang hasil penelitiannya menemukan bahwa kepuasan Kerja berpengaruh positif dan signifikan terhadap Kinerja karyawan. Namun hasil penelitian oleh Rahman et al., (2017) menemukan perbedaan hasil dimana kepuasan kerja bukan sebagai faktor penentu kinerja karyawan.

Dari hasil observasi ke beberapa BMT yang ada di Kota Pekanbaru, ditemukan ketidakpastian jenjang karir bagi karyawan BMT sehingga terdapat sebagian Karyawan BMT yang ketika awal bekerja sampai setelah bertahuntahun bekerja di BMT tidak pernah mengalami promosi jabatan (mendapatkan jabatan baru yang lebih baik) dan sebagian dari mereka juga beranggapan bahwa bekerja di BMT hanya sebagai batu loncatan untuk mendapatkan pekerjaan yang lebih baik. Dengan tidak adanya perencanaan karir yang jelas bagi karyawan BMT maka dapat berdampak pula terhadap kinerja karyawan BMT tersebut.

Salah satu fungsi penting manajemen karir adalah membuat perencanaan karir.Perencanaan karir tidak hanya menguntungkan pegawai secara perseorangan, tetapi juga menguntungkan organisasi. Organisasi mendapat jaminan tersedianya pegawai-pegawai yang cakap pada saat dibutuhkan organisasi. Bagi pegawai, program perencanaan karir memberikan kesempatan kepada pegawai untuk menyelidiki minat, kebutuhan dan pilihan karir dalam organisasi. Melalui proses perencanaan karir pegawai dibantu untuk menentukan tujuan-tujuan realistik dan untuk mengembangkan kecakapan dan kemampuan yang diperlukan untuk jabatan-jabatan sasaran. Raji et al., (2018) yang hasil penelitiannya menemukan bahwa Perencanaan Karir berpengaruh Positif dan signifikan terhadap Kinerja karyawan. Hasil penelitian sejalan dengan penelitian yang dilakukan oleh Mandriasih \& Iqbal (2019) yang hasil penelitiannya menemukan bahwa Perencanaan Karir berpengaruh positif dan signifikan terhadap Kinerja karyawan.

Berdasarkan

fenomena kinerja karyawan BMT yang telah di jelaskan di atas dan juga dukungan dari beberapa hasil penelitian terdahulu maka penelitian ini mencoba mengkaji bagaimana pengaruh perencanaan karir terhadap kepuasan dan kinerja karyawan. Dalam penelitian yang ditemukan sebelumnya masih minim penelitian yang menggunakan kepuasan kerja sebagai intervening dari perencanaan karir karyawan terhadap kinerja karyawan. 


\section{METODE PENELITIAN}

Penelitian ini dilaksanakan di Kota Pekanbaru kepada seluruh Baitul Maal Wat Tamwil (BMT) yang ada di Kota Pekanbaru.Populasi dalam penelitian ini adalah seluruh Karyawan Baitul Maal Wat Tamwil (BMT) yang ada di Kota Pekanbaru.Sampel adalah bagian dari jumlah dan karakteristik yang dimiliki oleh populasi tersebut. maka metode sampling yang digunakan dalam penelitian ini adalah total sampling (sensus) dengan jumlah responden sebanyak 79 responden.

\section{Teknik Pengumpulan Data}

Data dalam penelitian ini adalah data primer yang diperoleh dengan menggunakan metode observasi serta alat angket yang mana berisi sejumlah pertanyaan tertulis yang terstruktur untuk memperoleh informasi dari responden baik itu tentang pribadinya maupun hal-hal yang ingin diketahui. Metode pengumpulan data yang digunakan dalam penelitian ini adalah melalui teknik angket.

Dalam penelitian ini digunakan teknik angket langsung tertutup, sebagai teknik pokok untuk mengumpulkan data dari tiga variabel yaitu Perencanaan Karir, Kepuasan Kerja dan Kinerja Karyawan. Teknik angket langsung tertutup maksudnya adalah responden menjawab tentang dirinya sendiri serta tidak memberikan kesempatan kepada responden untuk menjawab pertanyaan yang diajukan dengan bahasanya sendiri.

\section{Teknik Analisis Data}

Model yang digunakan dalam penelitian ini adalah model kausalitas atau hubungan pengaruh.Untuk menguji hipotesis yang diajukan, digunakan teknik analisis SEM (stuctural equation model).Penelitian ini menggunakan SEM karena teknik multivariat yang menggabungkan aspek regresi berganda dan analisis faktor untuk mengestimasi rangkaian hubungan ketergantungan yang saling berhubungan secara simultan.

\section{Partial Least Square}

Dalam penelitian ini analisis data menggunakan pendekatan Partial Least Square (PLS). PLS adalah model persamaan struktural (SEM) yang berbasis komponen atau varian (variance).PLS merupakan pendekatan alternatif yang bergeser dari pendekatan SEM berbasiscovariance menjadi berbasisvariance.SEM yang berbasis kovarian umumnya menguji kausalitas atau teori, sedangkan PLS lebih bersifat predictive model.PLS merupakan metode analisis yang powerfull, karena tidak didasarkan pada banyak asumsi.Misalnya, data harus terdistribusi secara normal, sampel tidak harus besar.Selain dapat digunakan untuk mengkonfirmasi teori, PLS juga dapat digunakan untuk menjelaskan ada tidaknya hubungan antara variabel laten.

\section{HASIL DAN PEMBAHASAN}

Analisis Partial Least Square (PLS)

Dalam penelitian ini analisis data menggunakan pendekatan Partial Least Square (PLS) yang menggunakan software smartPLS.Partial Least Square (PLS) adalah model persamaan struktural (SEM) yang berbasis komponen variance. Pendekatan PLS adalah distribution free (tidak menggunakan data berdistribusi tertentu, dapat berupa nominal, kategori, ordinal, interval maupun 
rasio). Selain itu PLS juga dapat digunakan untuk mengukur sampel yang jumlahnya kecil.

Berikut ini tahap-tahap menggunakan pendekatan Least Square (PLS) dengan menggunakan software smartPLS:

\section{Convergent Validity}

Convergent Validity adalah model pengukuran dengan indikator refleksif berdasarkan korelasi antara skor item dan skor komponen dengan
PLS. Nilai factor loading hanya melihat hubungan antar indikator dengan konstruk eksogen. Nilai loading faktor yang $<0,5$ harus dikeluarkan dari model dan dilakukan estimasi ulang nilai factor loading. Dengan mengeluarkan beberapa nilai loading faktor $<0,5$ maka telah diperoleh nilai loading faktor yang telah di estimasi sebagai berikut :

Tabel 2. Loading Factor

\begin{tabular}{|c|c|c|}
\hline Variabel & Indikator & Factor Loading \\
\hline \multirow{13}{*}{ Perencanaan karir } & $\mathrm{X} 1.1$ & 0.685 \\
\hline & $\mathrm{X} 1.2$ & 0.751 \\
\hline & $\mathrm{X} 1.3$ & 0.622 \\
\hline & $\mathrm{X} 1.4$ & 0.633 \\
\hline & X1.6 & 0.682 \\
\hline & $\mathrm{X} 1.7$ & 0.553 \\
\hline & $\mathrm{X} 1.8$ & 0.595 \\
\hline & $\mathrm{X} 1.10$ & 0.541 \\
\hline & $\mathrm{X} 1.11$ & 0.730 \\
\hline & $\mathrm{X} 1.12$ & 0.623 \\
\hline & $\mathrm{X} 1.13$ & 0.810 \\
\hline & $\mathrm{X} 1.14$ & 0.730 \\
\hline & $\mathrm{X} 1.15$ & 0.682 \\
\hline \multirow{13}{*}{ Kepuasan } & Z1.1 & 0.778 \\
\hline & $\mathrm{Z} 1.2$ & 0.656 \\
\hline & $\mathrm{Z} 1.3$ & 0.823 \\
\hline & $\mathrm{Z} 1.4$ & 0.576 \\
\hline & $\mathrm{Z} 1.5$ & 0.566 \\
\hline & $\mathrm{Z} 1.7$ & 0.574 \\
\hline & $\mathrm{Z} 1.8$ & 0.583 \\
\hline & Z1.10 & 0.513 \\
\hline & Z1.11 & 0.531 \\
\hline & Z1.12 & 0.643 \\
\hline & Z1.13 & 0.686 \\
\hline & Z1.14 & 0.696 \\
\hline & Z1.15 & 0.668 \\
\hline \multirow{2}{*}{ Kinerja } & Y1.1 & 0.641 \\
\hline & Y1.2 & 0.601 \\
\hline
\end{tabular}




\begin{tabular}{lll}
\hline Variabel & Indikator & Factor Loading \\
\hline & Y1.4 & 0.539 \\
\cline { 2 - 3 } Y1.11 & 0.715 \\
\cline { 2 - 3 } Y1.12 & 0.587 \\
\cline { 2 - 3 } Y1.13 & 0.721 \\
\cline { 2 - 3 } Y1.15 & 0.524 \\
\hline
\end{tabular}

Sumber : Data olahan 2019

Berdasarlan tabel di atas, dapat dilihat bahwa hasilnya telah memenuhi convergant validity karena semua factor loading $>0.5$. Dengan demikian, dapat disimpulkan convergant validity dari seluruh kelompok konstruk endogen adalah valid.

\section{Discriminant Validity}

Model dikatakan mempunyai discriminant validity yang baik jika setiap nilai loading indikator dari sebuah variabel laten lebih besar berkorelasi dengan variabel laten tersebut dibanding bila dikorelasikan dengan variabel laten lainnya.

Tabel 3. Cross Loading

\begin{tabular}{|c|c|c|c|c|}
\hline Variabel & Indikator & Perencanaan & Kepuasan & Kinerja \\
\hline \multirow{13}{*}{ Perencanaan Karir } & $\mathrm{X} 1.1$ & 0.685 & 0.261 & 0.308 \\
\hline & $\mathrm{X} 1.2$ & 0.751 & 0.407 & 0.340 \\
\hline & $\mathrm{X} 1.3$ & 0.622 & 0.263 & 0.105 \\
\hline & $\mathrm{X} 1.4$ & 0.633 & 0.332 & 0.175 \\
\hline & $\mathrm{X} 1.6$ & 0.682 & 0.480 & 0.386 \\
\hline & $\mathrm{X} 1.7$ & 0.553 & 0.310 & 0.297 \\
\hline & $\mathrm{X} 1.8$ & 0.595 & 0.276 & 0.304 \\
\hline & $\mathrm{X} 1.10$ & 0.541 & 0.161 & 0.173 \\
\hline & $\mathrm{X} 1.11$ & 0.730 & 0.394 & 0.232 \\
\hline & $\mathrm{X} 1.12$ & 0.623 & 0.309 & 0.192 \\
\hline & $\mathrm{X} 1.13$ & 0.810 & 0.423 & 0.310 \\
\hline & $\mathrm{X} 1.14$ & 0.730 & 0.350 & 0.463 \\
\hline & $\mathrm{X} 1.15$ & 0.682 & 0.344 & 0.317 \\
\hline \multirow{10}{*}{ Kepuasan } & $\mathrm{Z} 1.1$ & 0.506 & 0.778 & 0.559 \\
\hline & $\mathrm{Z} 1.2$ & 0.300 & 0.656 & 0.301 \\
\hline & $\mathrm{Z} 1.3$ & 0.387 & 0.823 & 0.434 \\
\hline & $\mathrm{Z} 1.4$ & 0.185 & 0.576 & 0.201 \\
\hline & $\mathrm{Z} 1.5$ & 0.361 & 0.566 & 0.205 \\
\hline & $\mathrm{Z} 1.7$ & 0.420 & 0.574 & 0.204 \\
\hline & $\mathrm{Z} 1.8$ & 0.387 & 0.583 & 0.292 \\
\hline & $\mathrm{Z1.10}$ & 0.209 & 0.513 & 0.207 \\
\hline & $\mathrm{Z1.11}$ & 0.219 & 0.531 & 0.295 \\
\hline & $\mathrm{Z1.12}$ & 0.160 & 0.643 & 0.296 \\
\hline
\end{tabular}




\begin{tabular}{lllll}
\hline \multirow{5}{*}{ Z1.13 } & 0.229 & 0.686 & 0.353 \\
\cline { 2 - 5 } & $\mathrm{Z} 1.14$ & 0.436 & 0.696 & 0.281 \\
\cline { 2 - 5 } Kinerja & $\mathrm{Z} 1.15$ & 0.261 & 0.668 & 0.305 \\
\cline { 2 - 5 } & $\mathrm{Y} 1.1$ & 0.212 & 0.280 & 0.641 \\
\cline { 2 - 5 } & $\mathrm{Y} 1.4$ & 0.305 & 0.254 & 0.601 \\
\cline { 2 - 5 } & $\mathrm{Y} 1.11$ & 0.406 & 0.302 & 0.715 \\
\cline { 2 - 5 } & $\mathrm{Y} 1.12$ & 0.227 & 0.243 & 0.587 \\
\cline { 2 - 5 } & $\mathrm{Y} 1.13$ & 0.274 & 0.417 & 0.721 \\
\cline { 2 - 5 } & $\mathrm{Y} 1.15$ & 0.234 & 0.375 & 0.524 \\
\hline
\end{tabular}

Sumber : Data Olahan (2019)

Berdasarkan Tabel nilai loading factor untuk setiap indikator dari masing-masing variabel laten memiliki nilai loading faktor yang paling besar dibanding nilai loading factor jika dihubungkan dengan variabel laten lainnya. Hal ini berarti bahwa setiap variabel laten memiliki discriminant validity yang baik.

\section{Uji Reliabilitas}

Tahapan selanjutnya adalah pengujian konsitensi pengukuran (reliabilitas) dengan Average Variance Extract (AVE) dan
Composite Realiability (CR). Reliabilitas tinggi menunjukkan bahwa indikator-indikator mempunyai konsistensi tinggi dalam mengukur konstruk latennya. Reliabilitas dapat diketahui melalui nilai Composite Reliability (CR) dan Average Variance Extracted (AVE).Composite reliability dikatakan baik bila memiliki nilai $\geq$ 0.7.Nilai AVE dikatakan baik bila memiliki nilai $\geq 0.5$ (Ghozali, 2009).Data hasil pengujian AVE dan CR ditunjukkan pada tabel 4 berikut ini :

Tabel 4. Reliabilitas Konstruk

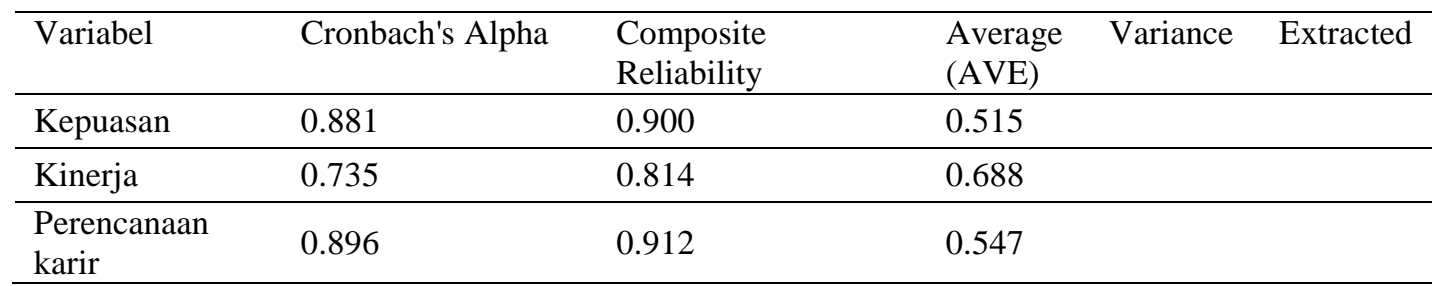

Sumber : Data Olahan (2019)

Berdasarkan hasil uji

validitas dan reliabilitas dari model pengukuran, dapat disimpulkan bahwa semua variable teramati valid mengukur variabel latennya, dan realiabilitas model pengukurannya pun baik.Hal ini menunjukkan bahwa indikator reliable dalam menyusun konstruk eksogen.

$\begin{aligned} & \text { Pengujian Model } \\ & \text { (Inner Model) }\end{aligned}$
Struktural

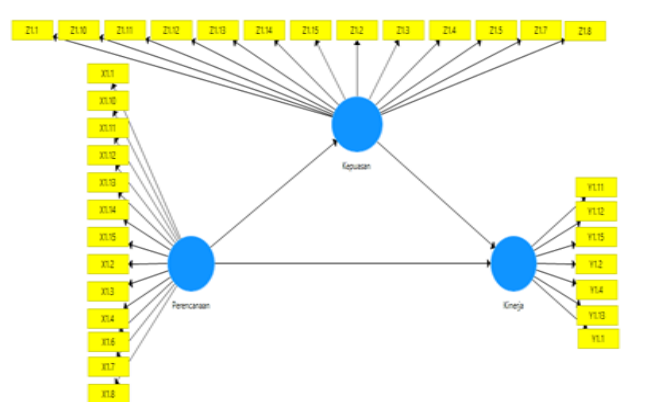

Gambar 1. Model Struktural 
Tabel 5. Pengujian R Square

\begin{tabular}{lll}
\hline Variabel & R Square & R Square Adjusted \\
\hline Kepuasan & 0.565 & 0.554 \\
\hline Kinerja & 0.692 & 0.669 \\
\hline
\end{tabular}

Sumber :Data Olahan (2019)

Tabel 6. Koefisien Path

\begin{tabular}{|c|c|c|c|c|c|c|}
\hline & $\begin{array}{l}\text { Original } \\
\text { Sample } \\
\text { (O) }\end{array}$ & $\begin{array}{l}\text { Sample } \\
\text { Mean } \\
(\mathrm{M})\end{array}$ & $\begin{array}{l}\text { Standard } \\
\text { Deviation } \\
\text { (STDEV) }\end{array}$ & $\begin{array}{l}\text { T Statistics } \\
(|\mathrm{O} / \mathrm{STDEV}|)\end{array}$ & P Values & Ket \\
\hline $\begin{array}{l}\text { Perencanaan karir } \rightarrow> \\
\text { Kinerja }\end{array}$ & 0.250 & 0.263 & 0.145 & 1.732 & $0.084 *$ & sig \\
\hline $\begin{array}{l}\text { Perencanaan karir }-> \\
\text { Kepuasan }\end{array}$ & 0.515 & 0.558 & 0.103 & 4.991 & $0.000 * * *$ & sig \\
\hline Kepuasan -> Kinerja & 0.367 & 0.390 & 0.141 & 2.597 & $0.010 * *$ & sig \\
\hline $\begin{array}{l}\text { Perencanaan karir -> } \\
\text { Kepuasan -> Kinerja }\end{array}$ & 0.189 & 0.217 & 0.093 & 2.037 & $0.042 * *$ & sig \\
\hline
\end{tabular}

Sumber : Data Olahan (2019)

\section{Uji R Square}

Berdasarkan Tabel 5 nilai adjusted R-square untuk variabel Kinerja sebesar 0.669. Hal ini berarti bahwa variabel Kinerja dijelaskan oleh variabel Perencanaan Karir dan Kepuasan sebesar $66.9 \%$.Sedangkan nilai Rsquare untuk variabel Kepuasan sebesar 0.554 yang berarti bahwa variabel Kepuasan Kerja dijelaskan oleh variabel Perencanaan karir sebesar $55.4 \%$.

\section{Uji Hipotesis}

Berdasarkan tabel 6 di atas maka hipotesis penelitian yang diperoleh adalah sebagai berikut :

H1.Terdapat pengaruh langsung antara perencanaan karir terhadap kinerja karyawan BMT di Pekanbaru

Dari hasil analisa statistik hasil uji $\mathrm{T}$ menunjukkan angka sebesar $1.732<\mathrm{T}$ tabel 1.67 dan nilai $\mathrm{P}$ Value menunjukkan perolehan 0.084 $<\alpha 0.1$ maka dapat disimpulkan H1 diterima dan artinya terdapat pengaruh langsung antara perencanaan karir terhadap kinerja karyawan BMT di Pekanbaru

H2.Terdapat pengaruh langsung antara perencanaan karir terhadap Kepuasan Kerja karyawan BMT di Pekanbaru

Dari hasil analisa statistik hasil uji $\mathrm{T}$ menunjukkan angka sebesar $4.991>$ T tabel 2.65 dan nilai $\mathrm{P}$ Value menunjukkan perolehan $0.000<\alpha 0.01$ maka dapat disimpulkan $\mathrm{H} 2$ diterima dan terdapat pengaruh langsung antara perencanaan karir terhadap Kepuasan Kerja karyawan BMT di Pekanbaru

H3.Terdapat pengaruh langsung antara kepuasan terhadap kinerja karyawan BMT di Pekanbaru.

Dari hasil analisa statistik hasil uji $\mathrm{T}$ menunjukkan angka sebesar $2.957>\mathrm{T}$ tabel 1.997 dan nilai $\mathrm{P}$ Value menunjukkan 
perolehan $0.010<\alpha 0.05$ maka dapat disimpulkan $\mathrm{H} 3$ diterima dan Terdapat pengaruh langsung antara kepuasan terhadap kinerja karyawan BMT di Pekanbaru.

H4.Terdapat pengaruh tidak langsung antara perencanaan karir terhadap kinerja melalui kepuasan kerja karyawan BMT di Pekanbaru

Dari hasil analisa statistik hasil uji $\mathrm{T}$ menunjukkan angka sebesar $2.037<\mathrm{T}$ tabel 1.997 dan nilai $\mathrm{P}$ Value menunjukkan perolehan $0.042>\alpha 0.05$ maka dapat disimpulkan $\mathrm{H} 4$ ditolak dan artinya tidak terdapat pengaruh tidak langsung antara perencanaan karir terhadap kinerja melalui kepuasan kerja karyawan BMT di Pekanbaru.

\section{Pengaruh Perencanaan Karir terhadap Kinerja Karyawan \\ Perencanaan karir adalah} suatu perencanaan tentang kemungkinan-kemungkinan

seseorang anggota organisasi sebagai perorangan untuk dapat meniti proses kenaikan pangkat dan jabatan sesusai dengan persyaratan dan kemampuannya. (Sitohang, 2007) Perencanaan Karir adalah proses penuh pertimbangan saat seseorang jadi memiliki pemahaman mengenai ketrampilan, pengetahuan, motivasi, dan karakteristik peribadi lainnya dan memantapkan rencana tindak untuk mencapai tujuan spesifik (Riyadi 2011). Perencanaan karir sangatlah penting bagi sebuah institusi termasuk Baitul Mall Wat Tamwil (BMT) sebagai bentuk motivasi kerja bagi karyawan supaya karyawan lebih bersemangat dalam bekerja yang akhirnya nanti akan meninkatkan kinerja karyawan tersebut. Perencanaan karir membuat kinerja karyawan lebih terarah dan terfokus karena karyawan lebih mengetahui target atau goal apa yang ingin mereka kejar untuk mendapatkan posisi jabatan di atasnya.

Hasil Penelitian ini menunjukkan bahwa perencanaan Karir berpengaruh Positif dan signifikan terhadap terhadap kinerja karyawan BMT yang ada di kota Pekanbaru dengan nilai $P$ value sebesar $\quad 0.084<\alpha$ a 0.1 . Hasil penelitian ini sama dengan penelitian yang dilakukan oleh Muhammad (2019) yang hasil penelitianya menemukan bahwa perencanaan karir berpengaruh positif dan signifkan terhadap kinerja karyawan Divisi Mikro Mitra Usaha Rakyat (MUR) PT. Bank BTPN cabang Pekanbaru. Hasil penelitian ini juga sama dengan penelitian yang dilakukan oleh Raji et al., (2018) yang hasil penelitiannya menemukan bahwa Perencanaan Karir berpengaruh Positif dan signifikan terhadap Kinerja karyawan.

\section{Pengaruh Perencanaan Karir terhadap Kepuasan Kerja \\ Kesempatan mendapat} promosi, supervisi, kolega kerja yang bagus akan mempunyai pengaruh positif terhadap kepuasan kerja. Adanya kesempatan promosi jabatan yang adil, mutu pengawasan yang bagus dari atasa, dan hubungan antar karyawan yang harmonis dalam perusahaan akan meningkatkan kepuasan kerja karyawan.

Hasil penelitian ini menunjukkan bahwa perencanaan karir berpengaruh positif dan signifikan terhadap Kinerja Karyawan BMT yang ada di Kota Pekanbaru dengan nilai $\mathrm{P}$ value sebesar $0.000<\alpha$ 0.01. Hasil 
penelitian ini sama dengan penelitian yang dilakukan oleh Muhammad (2019) yang hasil penelitianya menemukan bahwa perencanaan karir berpengaruh positif dan signifkan terhadap Kepuasan kerja karyawan Divisi Mikro Mitra Usaha Rakyat (MUR) PT. Bank BTPN cabang Pekanbaru. Hasil penelitian ini juga sama dengan penelitian yang dilakukan oleh Mandriasih \& Iqbal, (2019) yang hasil penelitiannya menemukan bahwa Perencanaan Karir berpengaruh positif dan signifikan terhadap Kinerja karyawan.

\section{Pengaruh Kepuasan Kerja terhadap Kinerja Karyawan}

sebagai Kepuasan Kerja didefinisikan menyenangkan atau emosi positif yang dihasilkan dari penilaian pekerjaan atau pengalaman kerja seseorang. Kepuasan kerja dihasilkan dari presepsi karyawan mengenai seberapa baik pekerjaan mereka menyediakan hal yang dipandang Penting.

Hasil penelitian ini menunjukkan bahwa Kepuasan Kerja berpengaruh positif dan signifikan terhadap Kinerja Karyawan BMT yang ada di Kota Pekanbaru dengan nilai $\mathrm{P}$ value sebesar $0.010<\alpha 0.05$. Hasil penelitian ini sama dengan penelitian yang dilakukan oleh Muhammad (2019) yang hasil penelitiannya menemukan bahwa Kepuasan Kerja berpengaruh positif dan signifkan terhadap Kinerja karyawan Divisi Mikro Mitra Usaha Rakyat (MUR) PT. Bank BTPN cabang Pekanbaru. Hasil penelitian ini juga sama dengan penelitian yang dilakukan oleh Rusby \& Hamzah (2017) yang hasil penelitiannya menemukan bahwa kepuasan Kerja berpengaruh positif dan signifikan terhadap Kinerja karyawan.

\section{PENUTUP}

\section{Kesimpulan}

1. Perencanaan Karir berpengaruh positif dan signifikan terhadap kinerja karyawan BMT yang ada di kota pekanbaru. Ini berarti untuk meningkatkan kinerja karyawan BMT yang ada di kota pekanbaru perlu di buatnya perencanaan karir pada masingmasing BMT karena dengan adanya perencanaan karir ini membuat karyawan BMT lebih bersemangat untuk bekerja yang akhirnya akan meningkatkan kinerja mereka.

2. Perencanaan Karir berpengaruh positif dan signikan terhadap kepuasaan kerja. Ini berarti untuk meningkatkan kepuasan kerja karyawan BMT yang ada di kota pekanbaru perlu di buatnya perencanaan karir yang jelas di setiap BMT. Perencanaan karir membuat pekerjaan karyawan BMT lebih terfokus dan terarah, mereka lebih mengetahui langkah-langkah yang harus di lakukan untuk mendapatkan jenjang jabatan yang lebih tinggi kedepannya.

3. Kepuasan Kerja berpengaruh positif dan signifikan terhadap kinerja karyawan. Ini berarti semakin meningkat kepuasan kerja karyawan maka semakin meningkat pula kinerja karyawan BMT yang ada di kota Pekanbaru. Oleh karena itu untuk meningkatkan kinerja karyawan BMT yang ada dikota pekanbaru, Maka masing-masing BMT harus meningkatkan lagi kepuasan kerja karyawannya. 


\section{Saran}

1. Di harapkan kepada seluruh BMT yang ada di Kota Pekanbaru untuk membuat perencanaan karir yang jelas bagi karyawannya supaya mereka lebih bersemangat dalam bekerja dan akan meninbulkan kepuasan kerja yang akhirnya akan meningkatkan kinerja mereka.

2. Bagi peneliti lainnya, Penelitian ini sebagai acuan untuk melakukan penelitian lebih mendalam lagi mengenai Perencanaan Karir, Kepuasan Kerja dan Kinerja Karyawan BMT yang ada di Kota Pekanbaru dari segala aspek.

\section{DAFTAR PUSTAKA}

Hamzah., Rusby, Zulkifli \& Hamzah, Z. (2013). Analysis Problem of Baitul Maal Wat Tamwil (BMT) Operation in Pekanbaru Indonesia Using Analytical Network Process (ANP) Approach. International Journal of Academic Research in Business and Social Sciences. 3(8).

Indrawati, A., D. (2013). Pengaruh kepuasan kerja terhadap kinerja karyawan dan kepuasan pelanggan pada rumah sakit swasta di kota denpasar. Matrik: Jurnal Manajemen, Strategi Bisnis dan Kewirausahaan.

Muhammad, A. (2019). The Effect of Managerial Competencies, Compesation and Career Planning Toward Employee Performance Through Job Satisfaction at PT. Bank BTPN Tbk Mikro Banking Division (MUR) Pekanbaru Branch.
Journal of Management Info (JMI). 6(1), 17-21.

Mandriasih, L. \& Iqbal, Ali, M. (2019). Pengaruh Perencanaan Karir terhadap Kepuasan Kerja dan Komitmen Organisasi di Mediasi oleh Pengembangan Karir.Jurnal Ilmiah Manajemen dan Bisnis (3)1, 27-37.

Purwati, A. A., \& Arnando, A. (2018). Pengaruh Motivasi Kerja Dan Lingkungan Kerja Terhadap Kinerja Karyawan Dinas Pendidikan Dan Kebudayaan Provinsi Riau. Procuratio: Jurnal Ilmiah Manajemen, 6(2), 225235.

Rusby, Z \& Hamzah, Z. (2017). Pengaruh Pengembangan Karir dan Budaya Organisasi terhadap Kinerja Melalui Kepuasan Kerja Guru Sekolah Kebangsaan Kebun Sireh Pulau Pinang. COSTING : Journal of Econonomic, Business and Accounting, 1(1), 56-67.

Rahman, S., Purwati, A.,A. \& Yazid, M.,H. (2017). Pengaruh Motivasi, Kepuasan Kerja, Dan Disiplin Kerja Terhadap Kinerja Karyawan Sabrina City Hotel Pekanbaru. Procuratio, 2(2), 138-152.

Riyadi, S. (2011).Pengaruh kompensasi finansial, gaya kepemimpinan, dan motivasi kerja terhadap kinerja karyawan pada perusahaan manufaktur di Jawa Timur." Jurnal manajemen dan kewirausahaan, 13(1), 40-45. 
Susilaningsih, N. (2008). Pengaruh

Kepemimpinan, Disiplin,

Motivasi, Pengawasan, dan

Lingkungan Kerja Terhadap

Kinerja Pegawai (Studi Pada

Badan

Perencanaan

Pembangunan Daerah

Kabupaten Wonogiri.

EXCELENT, 1(2). 